\title{
TUSC3 wt Allele
}

National Cancer Institute

\section{Source}

National Cancer Institute. TUSC3 wt Allele. NCI Thesaurus. Code C54364.

Human TUSC3 wild-type allele is located within 8p22 and is approximately 224 kb in

length. This allele, which encodes tumor suppressor candidate 3 protein, is involved in the $\mathrm{N}$-glycosylation of proteins. Down-regulation of TUSC3 gene expression is associated with several forms of cancer such as ovarian carcinomas. 